\title{
MODELOS DE MUNDO Y TÓPICOS LITERARIOS: LA CONSTRUCCIÓN FICCIONAL AL SERVICIO DE LA IDEOLOGÍA DEL PODER
}

\author{
RAMÓN PÉREZ PAREJo \\ Universidad de Extremadura
}

\section{EL CONCEPTO SEMIÓTICO MODELOS DE MUNDO Y SU PROYECCIÓN EN LITERATURA}

En este artículo utilizaremos un término nacido en la Semiótica de la Cultura y lo aplicaremos a la Literatura, donde entendemos que adquiere una interesante proyección. Me refiero al concepto modelos de mundo, creado por la Escuela de Tartu-Moscú a finales de los sesenta y, sobre todo, en los setenta ${ }^{1}$. Se trata de un grupo de pensadores semióticos -entre los que destacan Iuri Lotman y Boris Uspenski- que deriva del postformalismo soviético y que es necesario ubicar en la estela de la crisis de los modelos estructuralistas $^{2}$.

\footnotetext{
${ }^{1}$ Quiero quedar claro desde el principio que el modelo base del concepto modelos de mundo que utilizo es el de la Escuela de Tartu-Moscú en la línea directa que trazan los trabajos de I. Lotman y B. Uspenski (vid. 1970a, 1970b) y, algo después, Cesare Segre (1974: 13-17; 1985: 147 y ss.; 1990). Otras menciones que aparecerán en este artículo, como ciertos estudios de T. Albadalejo Mayordomo (1986), L. Doležel (1979, 1980 y 1988), Harshaw (1984), Ryan (1991), N. Goodman (1978) o C. Lévy-Strauss (1987: 39-46) son ilustraciones basadas unas veces en la Teoría de la ficción (las cuatro primeras) y otras en la Antropología (las dos últimas), y no apoyaturas de la tesis principal de este trabajo. Ya abordé una explicación más detallada del concepto en Pérez Parejo (2002: 21-41, 67-72). Realizo aquí una apretada síntesis.

${ }^{2}$ En esencia, el concepto es una reelaboración de la Semiótica contemporánea cuyos primeros brotes habría que buscar en la noción de «visión del mundo» (Weltansicht) del pensador Wilhelm Von Humboldt. Aunque existan claras diferencias en el desarrollo de estos dos conceptos, responden a una misma motivación en su génesis. La diferencia fundamental entre ellos es que Humboldt propone la visión del mundo como una dependencia del pensamiento con respecto al lenguaje. El pensar vendría determinado por cada lengua, de tal manera que cada una de ellas proporciona una visión «nacional» del mundo. Cada lengua expresaría — como señala Valverde, J. M.a, en Humboldt (1991: 19)— «una peculiaridad nacional, incluso un humor, un modo de ser, una raza...» El mismo J. M. ${ }^{a}$ Valverde advierte que esta teoría es «lo más romántico, en el sentido peligroso del tér-
}

Rlit, LXVI, 131 (2004), 49-76 
En síntesis, por modelos de mundo se entiende la percepción cultural que el sujeto tiene del mundo al que pertenece, un nuevo mundo resultante que, al haber pasado ya por el filtro de la cultura, difiere del mundo real ya que la cultura proporciona inconscientemente unas estructuras de percepción que deforman el objeto. La Literatura, que posee también sus

mino» de Humboldt. Por el contrario, las semejanzas entre ambas ideas resultan también evidentes. Por una parte el término es relativamente semejante. Segre y Lotman configuran su concepto desde la semiótica y la antropología cultural, más modernas y científicas, con las que no contaba Humboldt. Pese al halo romántico que atraviesa el concepto de Humboldt, creo que es de justicia señalar esta filiación. Vamos a ampliar un poco más para que se observen las vinculaciones. Humboldt aseguraba que no era la cultura, sino el idioma, el que generaba una determinada «visión de mundo» (Weltansicht), verdadero origen del concepto «modelos de mundo». Cada lengua expresa la peculiaridad nacional, el humor, la raza, las relaciones de parentesco, familiares, sociales. Sin embargo, esta teoría es demasiado romántica pues, teniendo en cuenta la época, ensalza demasiado el espíritu nacional. Carmen Galán (1994: 166-185) ha interpretado de forma más moderna $\mathrm{y}$, a nuestro juicio, atinada, la teoría de Humboldt sobre las relaciones entre lenguaje y «modelos de mundo». Para Humboldt, el lenguaje es el vínculo mediador entre la subjetividad del hombre y la objetividad del mundo. Las lenguas son distintas porque son distintas visiones del mismo mundo. Pero las lenguas no son sensu strictu ideologías, no afirman nada sobre el mundo, sino que su misión es ofrecerlo de cierta manera: «Las lenguas no prejuzgan de antemano, sino que prejuzgamos (...) mediante las lenguas» (ibíd., 184). Cada hablante está ligado a esa visión de mundo. La diversidad de las lenguas, con sus modelos de mundo, constituye para Humboldt una extraordinaria riqueza ya que permite desvelar el mundo de distintas maneras. Sin embargo, para Humboldt - como historicista - hay una unidad entre todas ellas porque están construidas sobre la misma síntesis. El análisis de cómo las lenguas ofrecen distintas estructuras para los mismos contenidos es clave para inaugurar la moderna ciencia del lenguaje (ibíd., 185). Lo cierto es que sólo en algunas lenguas se ha desarrollado cierto tipo de pensamiento. Recordemos las ideas de Jaspers al respecto, el cual defiende que la lengua determina el pensamiento, la ciencia y la espiritualidad de un pueblo. Sostiene que no se puede filosofar con la misma facilidad en todas las lenguas y, aunque todos los conocimientos sean traducibles a todas, eso no significa que tal conocimiento pudiera haber sido descubierto en cualquiera de ellas. En tres lenguas alejadas en el espacio - continúa Jaspers - se dio casi al mismo tiempo el paso a lo racional: griego, chino e indio. Sólo en estas tres lenguas el pensamiento racional fue original y no podrá volver a repetirse la frescura plena de lo originario, la pureza de llegar al concepto desde la intuición ingenua. Parece evidente que nuestra cultura está determinada por esa original forma de pensar de los griegos, o que nuestra espiritualidad está marcada por la forma de pensar y de expresarse de la cultura hebrea (Jaspers, 1948-1952: 163-169 y 184-185). Determinados estudios antropológicos (vid. Humboldt, 1990: 246 y ss.; Hagège, 1992) centran su objeto de investigación en demostrar la vinculación existente entre las sociedades y las estructuras lingüísticas, sobre todo a partir del análisis de los nombres propios, términos de parentesco (vid. Levy-Strauss, 1987: 56-61 y 66-73), metáforas más comunes, expresiones de salutación, clases sociales, alocutivos, formas de cortesía. Parece que el lenguaje viene a nuestro encuentro y nos hace hablar (Heidegger, 1959). La cultura está tan ligada al lenguaje que puede ser descifrada como un sistema de signos. Para Segre, las relaciones entre cultura y lenguaje son tan íntimas que muestran una misma estructura, probablemente debido a la presencia de la sintaxis (Segre, 1990: 16-17). 
propios mecanismos de transformación de la realidad, genera su propio modelo de mundo a través de las estrategias de la ficción, un nuevo mundo que establece unas relaciones complejas con el mundo real y que se exporta a los lectores a través de las páginas. Ese nuevo mundo o producto no es ni verdadero ni falso en relación a su adecuación con la realidad empírica. Debe considerarse verdadero dentro de una nueva esfera, la verdad poética (Doležel, 1979: 205), a la que no le hace falta su correlato real aunque derive de él pues no le es necesaria la autentificación (Doležel, 1988: 93). La construcción ficcional es el determinado acto de habla de una fuente autorizada, el narrador, el único agente válido para autentificar objetos y eventos dentro del mundo ficcional creado (Doležel, 1980: 120122). De cualquier modo, lo que nos interesa aquí subrayar es que ese desvío en relación a la realidad que se opera en toda transformación ficcional puede contener intereses ideológicos. Pero no nos adelantemos: vamos a exponer primero la propuesta semiótico-cultural de modelos de mundo de la Escuela de Tartu-Moscú y sólo después intentaremos justificar nuestra propuesta concreta sobre las posibilidades de aplicación que tiene este concepto en el ámbito de la Literatura.

La Escuela de Tartu-Moscú parte de la idea de que toda cultura, asentada sobre un lenguaje, crea un modelo de mundo, es decir, una forma de entenderlo, de hacerlo traer a la mente. Interpretar el mundo es dividirlo, darle nombres a las cosas, separar unas de otras, relacionarlas de un modo determinado (gramatical, semántico, metafórico, connotativo), configurar, en suma, el Cosmos desde el Caos. Según esta escuela, la cultura cuenta con un mecanismo estereotipador para hacer traer el mundo a la mente: el lenguaje. Vemos el mundo y lo interpretamos tal como el lenguaje nos lo trae. El mundo viene a nuestro encuentro hecho lenguaje. La cultura se encarga de codificar y descodificar los signos confusos que existen en el mundo hasta crear una semiosfera (mundo de signos autónomo, distinto a otras semiosferas) con la que el hombre se compromete. Así se va conformando un cosmos significativo, un jardín ordenado a base de signos inteligibles para los miembros de la comunidad. Esa semiosfera tiene como centro nuclear y estereotipador el lenguaje que, además de para comunicar, sirve para modelizar el mundo, para traerlo de determinado modo a nuestra mente. La función principal de una semiosfera es diferenciarse de las otras semiosferas en la misma medida que una cultura se define por oposición a las demás. Esa es precisamente su principal función. Al generar distintas percepciones de la realidad, las distintas culturas son antagonistas entre sí no en un sentido xenófobo sino de autodeterminación, ya que cada cultura se compromete con su mundo, con su modelo de mundo (Segre, 1985: 154155). La principal razón de ser y de existir de la Cultura es, precisamente, crear ese modelo de mundo a partir de tres principios: la memoria (como acumulación de información de la colectividad), el sistema (como genera- 
dor de estructuras) y su dimensión comunicativa, es decir, toda cultura habita en un sistema de comunicación social.

La Escuela de Tartu tiene como cimiento el concepto de sistema modelizante, esto es, el mecanismo mediante el cual una comunidad o individuo percibe el mundo al tiempo que modela el mundo para él. Una lengua puede condicionar - no decisiva pero sí sensiblemente- nuestra percepción del mundo. De modo que, tensando el hilo, el carácter «nacional» de una lengua así como su propio carácter histórico niegan la aspiración del lenguaje para expresar verdades universales (Sánchez-Pardo, 1991: 182-183). Partamos de la idea de que una cultura, lejos de ayudar a penetrar en los saberes desde diferentes perspectivas, impone una determinada forma de considerar la realidad que percibe. Una cultura - hecha de palabras y de ideología - fija tan tendenciosamente la percepción de la realidad que, según Cesare Segre, «no es posible escapar al punto de vista de una cultura particular para afrontar los problemas de la cultura en general si se sigue manteniendo la lengua de la cultura de origen» (1985: 156).

Pese a que el modelo de mundo resultante se derive de su condición social, no es posible crearlo al margen del interpretante y de sus mecanismos de percepción. El mundo no es una realidad objetiva sino una construcción cultural inevitablemente unida al sujeto que la percibe e incluso a los mecanismos biológicos de percepción con que ha sido dotado por la naturaleza. Como en el constructivismo, debe saberse que las representaciones del mundo son realmente construcciones culturales mediatizadas biológica y socialmente, de modo que siempre hay una relación íntima entre el observador y el mundo observado: la observación influye en lo observado, entre otras cosas porque en cualquier proceso de semiosis se requieren como mínimo esos dos actores. Nuestra intuición de la realidad es consecuencia de la interacción entre ambos. La conciencia personal, subjetiva, parapetada tras el yo, no desempeña una función pasiva en el proceso de construcción del modelo de mundo, sino que es actora de un proceso que en cierto modo lo refleja a su imagen y semejanza, al menos a la imagen y semejanza de los mecanismos cognitivos que posee. Según la física cuántica, el observador puede interferir en lo observado en el mero y simple proceso de observación. Recordemos que el universo está regido por el principio de la entropía. Vemos el mundo como lo podemos ver, con los dispositivos de percepción y abstracción con que la evolución nos ha dotado. No de otro modo ocurre en la creación de los modelos de mundo. Nos es imposible, por tanto, certificar con exactitud la veracidad del mundo o la existencia de valores al margen de una existencia biológica, unos modos de percepción, una mediación del lenguaje como sistema modelizante primario; todo ello al margen de una existencia contextual, espacial, social y temporal históricas que, por supuesto, mediatizan también decisivamente nuestra percepción del mundo. 
Además de todo ello, los sistemas culturales se asientan sobre un determinado discurso simbólico que acaba dominando al pensamiento y decidiendo nuestra percepción de la realidad. Salvador Pániker lo ha sintetizado perfectamente: «Más que vivir en la Percepción Pura de la Realidad, vivimos prisioneros del simbolismo del lenguaje. Nuestra percepción de la realidad viene filtrada por las categorías de nuestro mundo simbólico. El hombre no domina el mundo simbólico de su lenguaje, sino que es dominado y condicionado por él. Lo que nosotros llamamos Realidad no es más que lo que las categorías de nuestro lenguaje pueden asimilar. Digamos que el carácter relativo del lenguaje primitivo, en su gestación hace miles de años, se ha convertido en carácter absoluto y el hombre actual no sabe percibir más allá de este mundo simbólico absolutizado. Así la cultura se ha formado como proyección social del lenguaje humano y a la inversa se ha convertido en factor determinante en la formación de este mundo simbólico» (Apud Amorós, 1991: 197).

Nelson Goodman (1978: 25 y ss.) ha analizado los mecanismos propios de los modelos de mundo. Considera que el hombre configura la realidad - crea su mundo - mediante dos procesos: la unión y la separación de entidades, procesos que se producen simultáneamente. La aplicación de determinadas etiquetas y nombres a las cosas, así como su clasificación en especies y grupos, nos hace percibir la naturaleza conforme a los sistemas creados y no conforme a la realidad tal cual es. El ser humano conoce porque divide la realidad. El proceso de división/identificación descansa sobre la organización en entidades y géneros. Goodman pone el ejemplo de la palabra «nieve» para distintas culturas. Un esquimal desglosaría la nieve en materiales y colores distintos; sin embargo, en los trópicos, la nieve se verá como un conjunto uniforme. La organización sistemática de los elementos en géneros y grupos determina nuestra visión del mundo. En muchas ocasiones, una determinada percepción nos hace ver cosas distintas aunque estemos observando un mismo acontecimiento (el fondo, la forma, el conjunto, la parte de la cosa por su conjunto, la significación simbólica, etc.) María Rosa Lida (1959: 41 y ss.) nos muestra numerosos ejemplos de cómo los primeros conquistadores de América aplicaban su modelo de mundo al paisaje americano, nuevo para sus ojos; las descripciones de los conquistadores están absolutamente determinadas/distorsionadas por el sustrato cultural previo. De este modo describen el paisaje americano como el paraíso ideal de Dante, como el prado milagroso de Berceo o como el vergel de amor de Guillaume de Lorris y, en pleno Renacimiento, se describe el nuevo mundo como una nueva Arcadia literaria. Por poner un solo ejemplo significativo, Colón llama ruiseñores (pájaro que no ha pertenecido jamás a la fauna americana) a los pájaros cantores con los que se encontraba. Esto pone de manifiesto que el modelo de mundo puede también tener una raíz exclusivamente cultural y que, 
además, ese modelo de mundo «cultural» puede proyectarse sobre la realidad creando, obviamente, una concepción del mundo mediatizada por la cultura. En los ejemplos anteriores parece como si el modelo de mundo cultural previo hiciese posible que la naturaleza imite al arte, a la cultura.

Los modelos de mundo cuentan además con otras dos características: son diacrónicos y sociales. El modelo de mundo es cambiante e histórico como cualquier otro producto derivado de la cultura. Para C. Segre, el «modelo de mundo» lo proporciona cada cultura, cada lengua y cada época histórica, ya que no es algo fijo sino dinámico y diacrónico; es un fenómeno que está sujeto a la evolución del lenguaje y al devenir del tiempo $\mathrm{y}$, por supuesto, sólo puede darse dentro de una comunidad ya que es un producto social, como el mismo lenguaje (1985: 153). Ese proceso, según los semióticos de la Escuela de Tartu, tiene lugar porque la cultura posee un «dispositivo estereotipador estructural, función que desarrolla precisamente el lenguaje natural» (en Segre, 1974: 9), el cual tiene un carácter social y cultural sujeto a convenciones. La Cultura es un gran texto en el sentido amplio del término: todo lo sujeto a descodificación (Segre, 1977: 23) y, por consiguiente, un sistema modelizante (Segre, 1970: 10 y Eco, 1968: 478). Por tanto, puede emprenderse la construcción de una Semiótica de la Cultura general ${ }^{3}$. Es paradójico que ciertas culturas se han asentado sobre textos e iconos (recordemos la Biblia, El Corán, ciertas epopeyas, etc.) como si quisieran delimitar textual y gráficamente su modelo de mundo y, al tiempo, diferenciarse de los demás modelos. El estudio de una cultura como si estuviese transida de textualidad lo efectuó R. Barthes en El imperio de los signos (1970), donde el autor se enfrenta al Japón como si se enfrentara a un texto - codificable y descodificable-.

La Literatura, como cualquier producto artístico, también crea sus modelos de mundo, entre otras cosas porque está hecha de palabras y está organizada en géneros. Recordemos que M.-L. Ryan afirma que la cuestión de la ficcionalidad no se decide ni por las propiedades semánticas, ni estilísticas ni temáticas de la obra — pues éstas no aseguran su carácter ficticio-, sino que se establece a priori como parte de nuestras expectativas genéricas. Se considera un texto como ficción cuando conocemos el género y sabemos que está gobernado por las reglas del juego ficcional (Ryan, 1985: 204).

\footnotetext{
${ }^{3}$ Cesare Segre (1985: 55), basándose en los estudios de los semióticos rusos anteriormente citados, nos muestra algunos ejemplos de modelos de mundo formulados como esquemas de contraposición o pares de opuestos: «NOSOTROS-LOS DEMÁS» (los representantes de una cultura y los de las demás), oposición por la que es posible, incluso gráficamente, el sentido de centralismo o de periferia que tienen los representantes de una cultura; "INTERIOR-EXTERIOR» (lo que es interior y lo que es exterior al sistema cultural) por la que se representan las relaciones con lo sobrenatural mantenidas por supersticiones o religiones; «ESTO-AQUELLO» (lo que está cerca y lo que está lejos con respecto a los miembros de una cultura).
} 
Schmidt defiende que tanto ficción como realidad están basadas en convenciones culturales (Schmidt, 1984: 238) que muchas veces dependen del contexto histórico. La ficción literaria afecta tanto al carácter retórico de toda la literatura como a las relaciones que establece con la realidad y que no debe establecerse en términos de verdad o falsedad (Pozuelo Yvancos 1988: 21). La poética de la ficción más sólida afirma que de la obra artística no puede decirse en rigor que sea verdadera o falsa porque sus estatutos pertenecen a otra categoría. Difiere tanto de la verdad como de la mentira sin convertirse en otra tercera entidad. Se mantiene en esa línea fronteriza o liminar que las separa y las une simultáneamente, y eso es lo que distingue lo ficcional de otras producciones escritas. Por tanto, la ficción, en sí misma, genera ya un determinado modelo de percepción $y$, dentro de la ficción, veremos distintos modelos de mundo propuestos por los autores.

La literatura, pues, como sistema modelizante secundario, genera sus propios modelos de mundo que hay que analizar dentro de ese doble juego ficcional. Crear modelos de mundo es una tendencia natural en la Literatura, si entendemos natural como una actitud generativa y modelizante desde sus orígenes más remotos. La misma Escuela de Tartu extendió el término modelo de mundo a la Literatura ya que entendía que ésta constituía otro sistema modelizante de la realidad, en este caso secundario. La Literatura - como producto cultural asentado más aun que otros en el lenguaje porque es un modo peculiar de tratarlo y hacer uso de él- crea a su vez otros modelos de mundo (culturales) que, por supuesto, establecen vínculos con el mundo real, pero siempre, - como ficción que es- lo transforman o distorsionan de alguna manera, incluso al modo «realista». Por tanto, no interesa aquí analizar aquí cómo es el mundo real, sino cómo es ese otro mundo virtual que ha generado la literatura a partir de esa materia prima y, por supuesto, qué relaciones establece esa realidad virtual con la realidad a secas.

Las relaciones entre modelos de mundo sociales, culturales y literarios son muy ricas y complejas, y casi siempre están teñidas por la ideología de las clases dominantes. Lennard G. Davis desvela las claves ideológicas de estas relaciones centrándolas en la influencia de la novela sobre nuestra percepción de la realidad. Según este autor, leemos conforme a como es el mundo, pero también entendemos el mundo conforme a como leemos. Las fantasías, los diálogos, los conceptos que podemos tener sobre la belleza, la verdad, la identidad personal o la propia realidad dependen en buena medida de nuestras lecturas (Davis, 1997: 9-20). Los modelos literarios que han llegado a nosotros no son otra cosa que representaciones ficticias de la realidad. La cuestión, según Davis, no es preguntarse qué se ha producido en esa representación, sino cómo se ha producido: «Cuando alguien objete que una representación ha de ser necesariamente diferente de la 
realidad a mí me gustaría añadir que no podemos conformarnos simplemente con el hecho de la representación, sino que debemos analizar el modo de la representación: lo que se incluye, lo que queda fuera o lo que no se puede representar» (Davis, 1997: 77-78), ya que, como defiende este autor, en ese juego de dejar, tomar o transformar la realidad se hallan profundas razones ideológicas sostenidas por el poder. Es más, la estructura de los argumentos, los personajes, las localizaciones espaciales e incluso los diálogos responden también a razones ideológicas que proceden del poder, el cual defiende y sostiene así su modelo de mundo, su jerarquía social y, por supuesto, su dinero. Por su parte, Pierre Bourdieu, para realizar un análisis serio de la obra de arte, aconseja la aproximación a ésta a través de lo que denomina campo literario, esto es, a partir de la construcción de la realidad social, editorial, de las condiciones de producción y recepción de la obra, etc. porque todas ellas imponen la forma de ser de la obra. Las corrientes y los autores literarios se producen, precisamente, por lo que contribuyen a producir; las obras son síntomas de todo ese entramado de producción, poder y realidad social. La lógica de la economía y de las relaciones con el poder y las instituciones penetran en la composición, edición, recepción y distribución de las obras de arte en general, de modo que los modelos de mundo que reproducen las obras son modelos de mundo interesados (Bourdieu, 1992: 13-15; 319-330).

Sin perder de vista estas claves ideológicas de la conformación de modelos de mundo culturales y literarios, conviene también subrayar que los modelos de mundo creados por la literatura inciden a veces en nuestra forma de entender el mundo real, con lo que se produce, paradójicamente, una ósmosis. La literatura nunca es inocente. No existe influencia en una sola dirección: los libros aportan no sólo nuevos modelos de mundo intraliterarios o ficcionales, sino que esos modelos de mundo literarios pueden llegar a afectar a los modelos de mundo culturales y extraliterarios y, al cabo, pueden repercutir en la propia inteligibilidad del mundo. Roger Chartier defiende que los libros transmiten reglas y visiones del mundo, de modo que habría que analizar seriamente qué modelos de mundo se han construido en nuestros modos de leer y en nuestras propias lecturas, modelos de mundo que han derivado en buena medida de las lecturas escolares y de los clásicos de la modernidad entre los siglos XVI y XVIII (Chartier: 2000). ¿Nuestra percepción del tiempo - lineal, con principio y fin- no puede estar relacionada con nuestros hábitos de lectura? Por ello, entre otras cosas, nos supone tanto esfuerzo mental concebir el tiempo como una realidad regresable o suspendida. Los animales, que no tienen el lenguaje, viven en un presente atroz. El ser humano no puede experimentar su existencia fuera del espacio y del tiempo $\mathrm{y}$, además, siente las percepciones del espacio y del tiempo desde la profundidad y la perspectiva de su propia existencia que lo mediatiza todo. McLuhan concreta aún más: «El hom- 
bre tipográfico tiene un nuevo sentido del tiempo: cinemático, secuencial y pictórico» (1962: 332-337). Todo se debe a la presencia del lenguaje y, según McLuhan, a la existencia desde el siglo XVI de la proliferación de la escritura y de la coexistencia habitual del hombre con ella en las ciudades. Nuestra concepción lineal del tiempo ha sido también denunciada por la deconstrucción como un pilar básico de la «metafísica de la presencia» según la cual la Filosofía occidental se ha obsesionado desde siempre en buscar verdades inmutables y principios sólidos sobre los que asentar su cosmovisión (Derrida, 1967: 128 y 365). Y Steiner, sin salir del mismo tema, se pregunta con brillante concisión si el pasado tendría alguna existencia fuera de nuestra gramática (Steiner, 1967: 56).

La visión del mundo del lector se altera al leer. También percibimos el mundo conforme a nuestras lecturas. Un escritor no puede desligarse de su acervo de lecturas previas; siempre viaja con su biblioteca a cuestas. Y esa gran biblioteca puede muy bien distorsionar su percepción del mundo real. Algunos escritores de la talla de Jorge Luis Borges han centrado su obra poética y narrativa en la exploración de los límites difusos entre realidad, cultura y ficción (vid., Dällenbach, 1977: 201-202; Hutcheon, 1980: 53; Sanz Cabrerizo, 1995: 341-362). El poeta novísimo Guillermo Carnero, defendiendo las bases de su culturalismo, afina aún más esta idea arguyendo que toda persona culta posee dos ámbitos referenciales: el de su propia vida y el ámbito que le proporciona su formación. Este último campo referencial está poblado de obras de arte, lecturas, material cinematográfico, conocimientos históricos, etc. En cualquier persona culta esas do parcelas de conocimiento se relacionan inextricablemente. Este poeta ha afirmado que sus primeras experiencias intensas del paisaje se produjeron en las lecturas de las obras literarias, ya que la experiencia puede ser vital o cultural, y las dos se encuentran «natural y espontáneamente entrelazadas en el funcionamiento real del pensamiento y en la génesis, exploración y formulación de la emoción de una persona culta» (Carnero, 2000: 20-21).

Lo cierto es que la literatura ha generado y genera mundos, mundos paralelos, virtuales, cuyas relaciones con el mundo real dependen de múltiples factores. En todas las épocas los modelos de mundo literarios están relacionados con los modelos de mundo culturales, sociales y reales aunque ofrezcan una imagen distorsionada, deteriorada, difuminada o a veces nos muestren el revés de las imágenes. Todo ello independientemente del grado de desviación ficticia que mantenga con su imaginario real. Por poner un primer ejemplo, estamos de acuerdo con Guy de Maupassant ${ }^{4}$ y con

\footnotetext{
${ }^{4}$ Guy de Maupassant, en Bourdieu (1992: 481): «Dar la sensación de realidad consiste en conseguir la ilusión completa de la realidad, siguiendo la lógica corriente de los hechos, y no en transcribirlos servilmente en su sucesión sin orden ni concierto. De lo que deduzco que los Realistas de talento deberían más bien llamarse ilusionistas (...)
} 
los críticos de la novela del «Nouveau roman» ${ }^{5}$ en que, dentro de la ficción, la literatura realista no es más real que otro tipo de literatura. La novela realista no es más realista que la novela de ciencia ficción. No hay que mirar más que al narrador pretendidamente neutral y objetivo del realismo ${ }^{6}$. No es más real Fortunata y Jacinta o Doña Perfecta de Galdós que La metamorfosis o El castillo de Kafka. Tampoco diré que son menos reales sino que se sitúan en el mismo estadio de la ficción. Si cabe - por poner un ejemplo- en ocasiones parecen más realistas las obras de Kafka porque la anécdota que presentan es deliberadamente inverosímil $\mathrm{y}$, por tanto, se sitúa deliberadamente en un mundo irreal, ficticio. En cambio, las obras realistas quieren mostrar la anécdota como verosímil y presentar el mundo que presentan como real, cuando no hay nada más falso que algo ficticio que quiera pasar ante nuestros ojos como real.

Las razones del desvío del modelo de mundo literario en relación con el real son de distinto signo. Casi siempre responden a factores ideológicos promovido por el poder. Ahí están casi siempre las causas, pero nos interesa aún más medir la desviación, contemplar la distorsión de la realidad, preguntarnos por los motivos de la transformación. A veces una cari-

Con lo que cada cual sencillamente se hace una ilusión del mundo, ilusión poética, sentimental, alegre, melancólica, sucia o lúgubre según su naturaleza. Y la única misión del escritor consiste en reproducir fielmente esta ilusión con todos los procedimientos del arte que ha aprendido y de los que puede disponer».

${ }^{5}$ La ficcionalidad del arte también está sometida al devenir histórico, pues la consideración de lo que es ficción y realidad es contingente y mudable y varía de unas épocas a otras pues depende de los modelos culturales y de los modelos de mundo. La ficción es un fenómeno dinámico y «condicionado por la historia y la cultura» (Pavel, 1983: 179). Robbe-Grillet, del Nouveau Roman, pensaba que los conceptos de realismo y de realidad son más que discutibles: «La crítica académica, tanto en Occidente como en los países comunistas, emplean la palabra realismo como si la realidad estuviera ya enteramente constituida (ya sea para siempre o no) cuando el escritor entra en escena. Así pues considera que el papel de este último se limita a explorar y expresar la realidad de su época (...) Ahora bien, todo esto deja de tener sentido cuando uno se apercibe de que, no solamente cada cual ve en el mundo su propia realidad, sino que es la novela precisamente quien la crea. La escritura novelesca no se propone informar, como hace la crónica, el testimonio o la relación científica, sino que es ella quien constituye la realidad» (Robbe-Grillet, 1963: 180-181).

${ }^{6}$ La profesora Sánchez-Pardo defiende que ese narrador está ligado a cierto modelo de mundo que tiene sus raíces históricas y culturales a finales del XIX (Sánchez-Pardo, 1991: 157). Véase también, para aclarar el especial estatuto de la ficción en la literatura realista, el artículo de B. Harshaw (1984), en el cual, tras definir el enunciado literario como un «constructo fictivo», establece diversos «campos de referencia» dentro del ámbito ficcional que responden a grandes rasgos a distintos niveles de la ficción dentro de la literatura realista en relación a sus correlatos reales. Así, analiza el especial tejido de relaciones entre los paisajes, las ciudadeso los personajes de la novela realista en relación a sus correspondencias extraliterarias (1984: 151-157). Asimismo, analiza el grado o compromiso de veracidad de las aserciones en la voz del narrador (1984: 126-129). 
catura puede decir más de una persona que su propia fotografía digital objetiva (si es que una fotografía puede serlo, o si acaso la objetividad no fuese una ilusión más, la mayor de todas) porque la distorsión que efectúa tiene un significado. Como primer botón de muestra, conocido por todos, la Literatura creó en el Medievo un concepto del amor, el amor cortés (absolutamente automatizado y cristalizado) que, aunque no se ceñía totalmente a los usos amorosos de la época, sin embargo dice mucho más de la época (de su ideología, de sus hábitos, de su forma de entender el mundo) que cualquier documento de carácter realista. Por ejemplo, el amplio léxico bélico que se utiliza en el amor cortés no significa, obviamente, que fuesen práctica común ciertos hábitos sadomasoquistas, sino que todos los ámbitos de la vida estaban influidos culturalmente por la vida social, asentada en buena medida en continuas luchas, batallas, guerras, torneos e intrigas palaciegas, en suma, caracteres de una sociedad feudal y guerrera. Esa forma de entender el mundo, con todo su lenguaje a cuestas, tenía que proyectarse en todos los ámbitos de la vida, y mucho más en la literatura y el arte, que en buena medida son espejo de la sociedad, un espejo que puede estar más o menos distorsionado, pero que siempre deja ver el fondo, las líneas gruesas, las principales estructuras, el esqueleto, la sintaxis, el lenguaje: la literatura es ver el mundo tras un cristal esmerilado.

Llegar a cifrar el modelo de mundo real a partir del modelo de mundo literario, establecer sus continuos trasvases y preguntarse acerca de los porqués de sus desviaciones son cuestiones estrechamente relacionadas con la construcción del componente cultural de la literatura, tantas veces olvidado, y que puede resultar sumamente útil para ciertos análisis sociológicos, ideológicos, literarios y directamente culturales: pienso ahora, por ejemplo, en la utilidad que puede tener en el ámbito de las clases de español para extranjeros en niveles superiores. Ciertas producciones literarias, desde el surrealismo más profundo de Federico García Lorca a de la lírica primitiva popular o del romancero antiguo, están cargadas de un componente cultural ideológico, incluso erótico, muy complejos, como ha demostrado el medievalista Juan Victorio (1995: 9-42). Los silencios del Romancero, sus comienzos in medias res o sus finales inconclusos y abiertos; la parquedad de la lírica primitiva, sus continuas referencias a una naturaleza más simbólica que real, etc. hacen que sea necesaria la construcción de un componente cultural (derivado directamente del modelo de mundo de cada época cultural) para interpretar correctamente estos textos. Cuando una lectura es correcta y rica también significa que es una lectura más estética, más completa y más placentera, porque además de leer el propio texto con su anécdota relatada textualmente, el lector está leyendo el mundo, el modelo de mundo subyacente, está conociendo la sociedad, está vislumbrando la ideología del autor y al tiempo la de la sociedad. Además de estar viendo las palabras y los personajes está asomándose a las calles, abriendo las 
puertas y metiéndose en las cocinas y en los dormitorios, espiando en los confesionarios, presenciando las conversaciones más íntimas y las decisiones más terribles. Porque el que lee con el componente cultural, conociendo el modelo de mundo existente reflejado en la literatura, es capaz, además de leer la historia lineal, de leer entre líneas los miedos de los protagonistas, sus angustias, sus alegrías, es capaz de comprender sus decisiones y de dar sentido no sólo a lo que dicen y a lo que hacen, sino a lo que ocultan, omiten o callan, que casi siempre es lo más importante.

\section{ERNST R. CURTIUS: TÓPICOS Y MODELOS DE MUNDO LITERARIOS}

A mi juicio, el filólogo que con más profundidad, acierto y saber enciclopédico ha estudiado el conjunto de la literatura europea en la Edad Media ha sido Ernst Robert Curtius. 'Para él, la literatura europea es un todo orgánico que arranca desde Grecia y Roma y se mantiene con gran vigor y renovación a lo largo de la Edad Media. Ahora bien, las filologías nacionales han centrado su interés en las lenguas vernáculas, y han dejado al margen - marginada - la literatura creada en los diez siglos que hay entre la «decadencia» de la literatura romana y la aparición de las grandes obras del Renacimiento italiano del Quatroccento y Cinqueccento, entre ellas, la Divina Comedia de Dante. Y en esos diez siglos floreció una literatura escrita en su gran mayoría en latín, extraordinaria y variadísima, que ha sido desdeñada por la filología moderna y contemporánea. En ese periodo y en esas obras escritas en latín - la lengua aún de la cultura durante todo el medievo, recordemos- se centra el filólogo alemán en su clásico Literatura europea y Edad Media Latina (1948). ¿Por qué nos interesa aquí y por qué también interesó a Curtius? Las literaturas en las modernas lenguas vernáculas y romances no nacen de la nada; continúan en distinta lengua la tradición literaria de toda la Edad Media, extenso y vasto momento en que se forjaron los hábitos retóricos de la literatura posterior. Pero también su estilo, sus géneros, su filosofía, etc. Todas las obras medievales de la literatura española culta, desde el Libro de Aleixandre a La Celestina pasando por Los Milagros de Nuestra Señora (cfr. Garrido Gallardo, 1979) beben en fuentes de la literatura medieval latina. Cualquier acercamiento a sus influencias da fe de ello.

Pues bien, entre las fuentes en las que bebe la literatura medieval romance, destaca la de los tópicos literarios. Recordemos que tópicos son sistemas codificables de variaciones formales sobre un tema. No queremos aquí identificar los conceptos de tópicos y modelos de mundo, tan sólo pretendemos trazar las conexiones que se establecen entre ellos. En los tópicos literarios los autores seleccionan el mismo motivo para expresar una temática codificada por una tradición y ligada a un lenguaje y a unas 
formas, es decir, a unos clichés y diseños retóricos, lingüísticos, morfosintácticos y formales automatizados. Todos los poetas y los oradores, cuando se referían a un tema determinado, han recurrido a ellos como si fuesen un «almacén de provisiones». E. R. Curtius ha estudiado con gran perspicacia el sistema de tópicos de la literatura medieval escrita en latín, corpus que pasa íntegro a la literatura vernácula de toda Europa (1948: 122159). Entre los tópicos, Curtius estudia la tópica de la consolación, la de la historiografía, la falsa modestia, la del exordio, la de la conclusión, la invocación a la naturaleza, el mundo al revés, el niño y el anciano y, por último, la anciana y la moza (ibíd., 122-159). A ellos habría que sumar, como poco, otros tópicos de fabulosa productividad, especialmente en la Baja Edad Media, tales como el del «carpe diem», «locus amoenus», «locus agrestis», «tópico del jardín» o el «hortus conclusus», «tempus fugit», «inevitabilidad de la muerte», ¿ubi sunt?», «vanitas vanitatum», «puer senex», «somnus imago mortis», «beatus ille», «tópico del amanecer y del atardecer sangriento», «signa amoris», «nullus sermo sufficiat o tópico de la indecibilidad», «tópico de las musas o del furor poético», «el mundo como texto», «el mundo como teatro», «la fama o tópico de la posteridad», «la albada» etc. No entraré ahora a detallar estos tópicos; remito al estudio de E. R. Curtius y a cualquier estudio de retórica serio que los trabaje en profundidad.

Lo que me interesa ahora destacar es que la insistente recurrencia a los tópicos, sobre todo en la literatura medieval, denota que los autores seleccionan imaginarios culturales, no reales, y su significado está dentro de ese mundo y sancionado por una tradición literaria. Los autores, al hacer uso de los tópicos, no se están refiriendo al mundo real sino a la propia literatura y es aquí donde entra a jugar un papel el modelo de mundo. $\mathrm{Y}$ nada mejor para demostrar que los tópicos pertenecen a la cultura y no a la vida que acercarse a la obra que quizá mejor expone la lucha entre la realidad y la ficción: Don Quijote de la Mancha de Cervantes. El protagonista, Don Quijote, ve el mundo a través del filtro de la cultura, más concretamente a través de los libros de caballería, que no son sino otro modelo de mundo literario totalmente cerrado, acartonado, previsible. Cuando Don Quijote sale por primera vez de su pueblo vestido de caballero, «hablando consigo mesmo» - lo cual ya denota algo - le oímos recurrir al tópico del amanecer, tan transitado en la literatura caballeresca, la pastoril y la sentimental, cortadas todas por la misma tijera en cuanto a su relación con el mundo real. Por supuesto, aquí Cervantes parodia el lenguaje y los tópicos de las novelas de caballerías. El ingenioso caballero describe el amanecer del siguiente cuño en el capítulo I:

"¿Quién duda sino que en los venideros tiempos, cuando salga a la luz la verdadera historia de mis famosos fechos, que el sabio que los escribiera no 


\begin{abstract}
ponga, cuando llegue a contar esta mi primera salida tan de mañana desta manera: «Apenas había el rubicundo Apolo tendido por la faz de la ancha y espaciosa tierra las doradas hebras de sus hermosos cabellos, y apenas los pequeños y pintados pajarillos con sus arpadas lenguas habían saludado con dulce y meliflua armonía la venida de la rosada aurora, que, dejando la blanda cama del celoso marido por las puertas y balcones del manchego horizonte se mostraba cuando el famoso caballero don Quijote de la Mancha, dejando las ociosas plumas, subió sobre su famoso caballo Rocinante y comenzó a caminar por el antiguo y conocido campo de Montiel».
\end{abstract}

En el ámbito de los tópicos la literatura se refleja a sí misma, se hace un bucle, deja de referirse al mundo para referirse a un modelo de mundo. Debemos interpretar correctamente estos tópicos, saber dónde están y cómo han sido codificados formalmente para poder entenderlos, ya que un lector, sobre todo si no pertenece a la tradición occidental, puede incurrir en un dislate interpretativo. Los tópicos tienen, además de unas coordenadas geográficas, unas coordenadás históricas y contextuales, determinadas de alguna manera por la sociedad. E incluso, lo más importante, es que el mismo tópico puede haber existido en diversos momentos históricos pero «el estilo en que se expresan (...) está siempre condicionado históricamente» (Curtius, 1948: 127). De modo que son testimonio de una actitud espiritual y también de una forma de entender el mundo y de crear un modelo de mundo literario determinado. Quiere decirse que los tópicos son como son por la sociedad en que fueron creados $\mathrm{y}$, por tanto, responden a un modelo de mundo del que son productos dignos de atención al estar cristalizados. Son fósiles, y ya sabemos, por la arqueología, que los fósiles hablan. Sólo hay que saberlos escuchar.

\title{
3. Automatización IDEOLÓGICA DEL MODELO DE MUNDO DEL AMOR CORTÉS
}

Comenzaremos por el tópico más codificado de todos, el del amor cortés. La conformación de este tópico literario está estrechamente relacionado con el modelo de mundo que se quiere mostrar. El tejido iconográfico del tópico del amor cortés genera un modelo de mundo literario que, aunque tenga su fuente referencial en la realidad, muestra sin duda un modelo distorsionado e interesado de los hábitos amorosos de la época.

En la Provenza del siglo XII se acuñó el tópico del amor cortés y desde allí se difundió por toda Europa a través de la composición típica de esta poesía, la cansó, compuesta e interpretada por trovadores. En ella el sujeto lírico ama tanto a la dama que está entregado a su servicio; él se presenta como vasallo, y la dama aparece como señor feudal. Pero la veneración del caballero hacia la dama es un mero juego formal: 


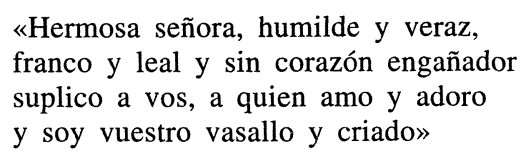

Se trata de la transposición de las relaciones sociales del feudalismo al ámbito amoroso: el poeta se declara siervo de la dama, a la que llama $m i$ señor ( «Vostre sui ieu, domna, non de mé/ per qu'ieu vos dei temer e obesir/ (...) / que nuit e jorn ieu no pes ne cossir/ mas que us porai al vostre grat servir». Los poetas expresan sus padecimientos y se lamentan continuamente enarbolando su dolor como el más agudo de los posibles. $\mathrm{Su}$ amor es un problema sin solución, un infierno en el que no hay salida, un laberinto, una paradoja en la que se enredan y nos enredan ( $\ll \mathrm{Ni}$ muer, ni viu ni no guaris,/ ni mal no'm sent, e si l'ai grant/ quar de s'amor no suy devis;/ non sai si ja aurai ni quand (qu'en lieys es tota la mercés/ que'm pot sorzer e decazer». Se transmite continuamente la idea de que el sentimiento amoroso lo invade todo y los seres humanos no pueden huir de él; el amor es inevitable. La amada aparece sublimada como ejemplo de virtud, perfección y belleza en una auténtica y sacrílega religio amoris -que tendrá su punto culminante y su parodia en La Celestina cuando, tras preguntar Melibea a Calixto qué religión profesaba, éste le responde: «Melibeo soy»-, aunque prevalece más la descripción del estado amoroso del sujeto lírico que la descripción de la dama. Para describir a la dama habrá que esperar al Renacimiento. De cualquier modo, el amor entra por los ojos - se destaca la importancia de la mirada en el juego amoroso- y se convierte en una especie de batalla en la cual el sujeto lírico lucha contra la amada, contra él mismo y contra la ausencia. En esa batalla de amor se eligen armas, se lanza el ataque, se defiende, se lucha, se hiere, se vence, se conquista, se caza. Con el amor, él ha perdido su libertad y su razón y tiene enajenados los sentidos («Los hombres de amor tocados/ ni sienten, ni oyen, ni ven»). O en La Celestina de Fernando de Rojas, donde leemos: «...No ven, no oyen (...) Que ni comen, ni beben, ni ríen, ni lloran, ni duermen ni velan, ni hablan ni callan, ni penan ni descansan, ni están contentos ni se quejan, según la perplejidad de aquella dulce y fiera llaga de sus corazones». Este «servicio» o amor a la dama ennoblece el espíritu del enamorado; su propósito es alcanzar la «prenda» o «galardón». El amor es una especie de guerra no sólo con la amada, sino con uno mismo, que debe pelear contra unos sentimientos que le dominan; cuando no, el amor es una cárcel, un castillo imposible de atacar o un día de caza en el que las aves simbolizan a las damas, tan hermosas e inalcanzables unas como otras. Sin embargo, la honestidad de la dama impide los deseos del amante, por ello es acusada de ingrata y cruel; la frustración de éste se transforma en sufrimiento y dolor inevitable (pues es imposible dejar de amar), lo que le hace enfermar y desear la muerte. 
«No tardes, Muerte, que muero; ven, porque viva contigo; quiéreme, pues que te quiero, que con tu venida espero no tener guerra conmigo»

JUAN DEL ENCINA

Y hasta aquí sólo el desarrollo temático. Pero el amor cortés afecta a otros planos: léxico-semántico, metafórico, estilístico, narratológico, rítmico, estrófico, sintáctico. En primer lugar, resaltemos la complejidad retórica de la que hacen gala los poetas de cancionero: derivaciones, políptoton, quiasmos, paradojas, derivaciones, hipérboles, juegos conceptuales, contrastes, comparaciones; a nivel narratológico, la omnipresencia del yo, del reflejo de los propios sentimientos, de la primera persona reflejada en la omnipresencia de pronombres y posesivos; en el plano rítmico, sintáctico y estrófico, la utilización de 'estrofas cortas con estribillos continuamente repetidos al final de las mismas, la presencia de anáforas al comenzar los versos, el ritmo lógico de los extensos periodos paralelísticos; en el plano léxico-simbólico, la aparición del léxico guerrero, cazador, aristocrático. Un ejemplo clásico de cómo el tema del amor cortés y los males del amor se encapsulan en cierta retórica es una intervención de Celestina hablando con Melibea mientras le describe qué es el amor. Recordemos que La Celesti$n a$ tiene mucho de parodia del amor cortés, y por eso mismo recurre a él. Es más, yo diría que La Celestina es una obra realista que enfoca de modo realista un modelo de mundo literario, lo que consecuentemente conduce a la tragedia. Como decimos, el personaje de la Celestina recurre a contrastes y paradojas dentro de una hipálage, es decir, la adscripción de un adjetivo a un sustantivo semánticamente opuesto: «Es un fuego escondido, una agradable llaga, un sabroso veneno, una dulce amargura, una delectable dolencia, un alegre tormento, una dulce y fiera herida, una blanda muerte». Este mismo recurso sería utilizado, entre otros, por Quevedo en su soneto «Es hielo abrasador, es fuego helado,/ es herida que duele y no se siente, / es un soñado bien, un mal presente,/ es un breve descanso muy cansado ...». Y quizá el ejemplo culminante, para entender de paso la pervivencia del tópico, sea el soneto de Lope de Vega «Esto es amor: quien lo probó lo sabe», que comienza «Desmayarse, atreverse, estar furioso...».

Este panorama de desarrollo temático, formal y estilístico, ya acuñado en la poesía provenzal del XII, sólo sufre levísimas modificaciones. Influirá notablemente en la lírica gallega de los siglos XIII y XIV a través de la Ruta de Santiago y, muy en especial, en la poesía catalana, en la que el provenzal llegó a imponerse como lengua poética. Influyó decisivamente en el padre de la lírica renacentista, Petrarca, en los cancioneros españoles del siglo XV y, por supuesto, en el Renacimiento, Barroco y en toda la literatura posterior, que en este tema no ha sido más que un ir y venir a 
las fuentes del amor cortés para tomar, dejar, homenajear, parodiar, intertextualizar, etc. Y el amor cortés late como homenaje cuando leemos a Lorca en los Sonetos del amor oscuro («Amor de mis entrañas, viva muerte» o cuando en el «Soneto de la dulce queja» dice «si eres mi cruz y mi dolor mojado,/ si soy el perro de tu señorío») y late como parodia en el «Soneto del amor de oscuro» de Luis Alberto de Cuenca:

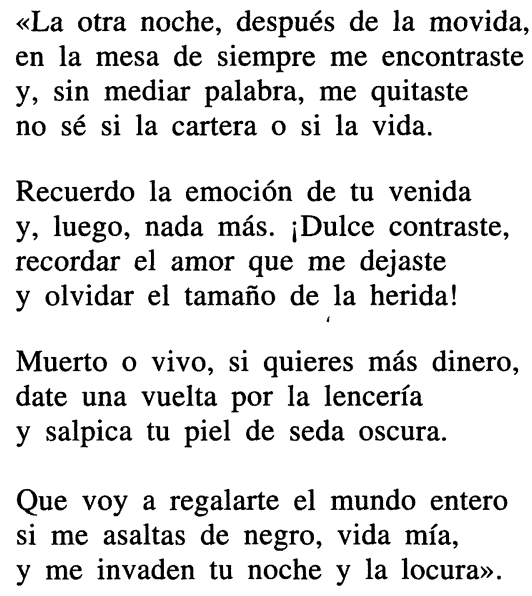

Se trata de una parodia con intenciones irónicas. Mezcla el estilo coloquial contemporáneo ( «la otra noche, la movida, la cartera, el dinero, la mesa de siempre, date una vuelta») con el estilo de la lírica amorosa del amor cortés. Éste se aprecia en numerosos indicadores que afectan a distintos planos: el título homenajeando al Lorca de los «Sonetos del amor oscuro»; la estructura estrófica utilizada, el soneto, la más emblemática de la lírica petrarquista y postpetrarquista (Pozuelo, 1979); la concepción del amor como lucha; el uso del oxímoron («dulce contraste»), del contraste («muerto o vivo»), los paralelismos de los versos 7 y 8 ; la enajenación o confusión de los sentidos («No sé si la cartera o si la vida»), etc. Además, para cerrar el círculo, apenas hay contacto físico o éste es mínimo: el suficiente para robar la cartera al sujeto lírico. La herida, siempre identificada con la herida del amor cortés, aquí desautomatiza su significado cortesano pasando a significar el robo del dinero. Como vemos, se parodian estructuras léxico-semánticas, sintácticas y metafóricas del amor cortés.

El código del amor cortés influyó decisivamente en toda la lírica posterior que tuviera como tema el amor. Pero no sólo afecta a la Literatura, sino que - retomando el hilo - afecta a la vida, ya que no siempre es la vida la que afecta a la literatura; hay una continua ósmosis. No debemos olvidar que a veces la realidad supera al arte y que a veces la vida imita 
al arte. Así que este concepto nacido y plasmado en la Literatura se ha extrapolado al mundo real, al punto que Torrente Ballester, irónicamente, afirmaba que el amor nació en la Provenza. Obviamente, quería decir que nuestro concepto real del amor está totalmente influido por nuestro concepto cultural, artístico y literario del amor, el cual bebe directamente de las fuentes del amor cortés. Al hilo de esto, un ensayo poco sospechoso de ser literario a no ser por su calidad de escritura, como el de Juan Antonio Marina, El rompecabezas de la sexualidad (2002), llega a la misma conclusión desde un punto de partida distinto: su tesis principal es que una cosa es el sexo como material y acción biológica y orgánica y otra la sexualidad - que es realmente lo que tenemos-, esto es, un complejo de concepciones, estereotipos, tópicos, imágenes y percepciones culturales que llegan a nosotros por tradición, sociedad y cultura. Nuestra sexualidad - y en el término incluye Marina el concepto del amor - no es otra cosa que un modelo y código cultural, no es la sexualidad, sino $m i$ sexualidad, $m i$ concepto, totalmente atravesado por la cultura. Lo mismo ocurre con el concepto del amor en sí mismo, está atravesado por la cultura de parte a parte, y un gran protagonismo lo tiene la retórica del amor cortés. Para ver cómo se confunden realidad y ficción literaria no hay más que acercarse a un humanista del XVI, Baltasar de Castiglione, el cual se extraña al conocer las fatigas que pasaban los enamorados literarios:

«Así que estos tales enamorados aman pasando vida congoxosa y miserable; porque o nunca alcanzan lo que desean, que no puede ser mayor trabajo, o verdaderamente si lo alcanzan, hállanse haber alcanzado su mal, y acaban su miseria con otra mayor miseria; porque no solamente en el cabo, mas aun en el principio y en el medio de este amor nunca otra cosa se siente sino afanes, tormentos, dolores, adversidades, sobresaltos y fatigas; de manera que el andar ordinariamente amarillo y afligido en continuas lágrimas y sospiros, el estar triste, el callar siempre o quejarse, el desear la muerte $y$, en fin, el vivir en extrema miseria y desventura, son las puras cualidades que dicen propias de los enamorados»

(Castiglione, 1972: 424-425)

El modelo de amor (en este caso el amoroso) está codificado, el discurso retórico, la variatio dictada, la temática modulada ¿Por qué se produce todo esto? ¿Qué elementos extraliterarios concurren para diseñar un modelo de amor semejante? ¿Por qué se acuña en esas monedas retóricas? ¿Por qué sufre sólo levísimas modificaciones? ¿Cuál es exactamente su relación con la realidad? ¿Cómo hay que entenderlo? Para responder a todo esto y explicar cómo se ha codificado este modelo nada mejor que intentar esbozar un «campo literario» a la manera de Pierre Bourdieu (1992), es decir, trazar el contexto histórico-político-estético-cultural de escritura, edición y recepción de las obras literarias del amor cortés (especialmente el que aparece en el siglo XV, quizá su cristalización) que hace posible la 
aparición y el desarrollo de esta estética. Y para ello nada mejor que ir de la mano de uno de los críticos que, a mi juicio, mejor ha explicado la recepción - y con ello la creación - de este tipo de obras del siglo XV. Me refiero a Antonio Serrano de Haro en su clásico estudio (Serrano de Haro, 1975) sobre la obra de Jorge Manrique, quizá la figura más señera de cuanto venimos diciendo, y no me refiero aquí a sus Coplas a la muerte de su padre, sino al conjunto de su injustamente semiolvidada poesía amorosa.

Serrano de Haro parte de la convicción de que la poesía de Jorge Manrique y Jorge Manrique mismo son productos arquetípicos de la sociedad de su época, la aristocracia del siglo XV (Serrano de Haro, 1975: 1314), que, junto con los clérigos, era la única clase culta $y$, por tanto, la única que podía producir obras de arte. Lo decimos porque toda la poesía de Cancionero está escrita por este tipo de gente. Los Manrique, emparentados con la realeza, tienen una concepción nobiliaria de la vida, de la sociedad, de la política. La honra, la caballerosidad, la fama, el honor, la valentía, la lealtad y la defensa de su «estado» son los pilares básicos de su forma de entender las relaciones personales. En efecto, la visión de la sociedad en estamentos perfectamente definidos es algo que luego se ve reflejado en la poesía. La amada es siempre la señora de quien el amante es vasallo. Estamos descodificando uno de los pilares simbólicos de la poesía del amor cortés del Cancionero. Si el sujeto lírico se muestra como un vasallo de su señor (la dama) es porque sencillamente así están diseñadas las relaciones sociales, y desde aquí se extrapolan al ámbito del mundo amoroso, al menos al literario:

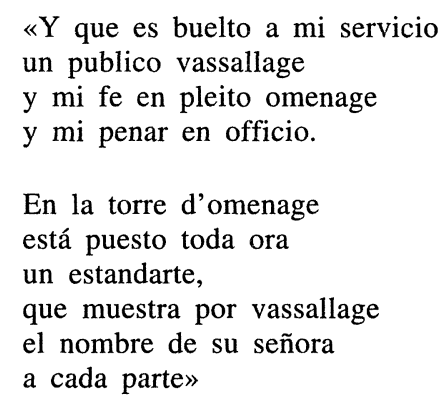

En el anterior poema percibimos, además, el símbolo del castillo o de la fortaleza. Éste está omnipresente en la poesía cancioneril. La explicación parece evidente: la vida del $\mathrm{XV}$, para estos señores, transcurría en los castillos y palacios. Entonces, para explicar la dificultad de vencer la resistencia de la dama, el símil más a mano era el de la resistencia de una fortaleza típicamente medieval como la de los castillos. Todo responde a la psicología militar de Jorge Manrique, producto directo de su formación, 
y de la sociedad en la que se desarrolló su vida (Serrano de Haro, 1975: 147 y ss.). Rara es la composición del amor cortés sin presencia militar en el plano léxico-simbólico, y mucho menos en la poesía amorosa de Jorge Manrique. Baluartes, ejércitos, banderas, guerras y batallas, celadas, puñales, armaduras, escudos, corredores, amenazas, contiendas, rabias, enemigos, fortalezas, cercos, sitios, retos, porfías, torneos, traiciones, desafíos, fortuna, corredores, puentes levadizos, fosos, son algunos de los motivos más transitados por la poesía cortés de Manrique. Ni que decir tiene que todos ellos están utilizados metafóricamente, y que toda metáfora cuenta con un término real y un término imaginario. Lo importante ahora es subrayar cómo el término real de todas estas metáforas puras reenvía a un determinado mundo, a un determinado modelo de mundo, el del momento, el del país y el de la ideología de la clase poderosa. La consecución del amor es una «Escala de amor», un asalto. Los símiles y las metáforas bélicas aparecen por doquier, incluso, como afirma Serrano de Haro (ibíd. 148 ), en poetas de este tiempo y posteriores que no tuvieron ninguna actividad bélica, como Juan de Mena y Villasandino, o Álvarez Gato. Incluso ideológicamente se percibe la huella de la sociedad en la que esta poesía se desarrolla, por ejemplo, la creencia en la fuerza como medio lícito, la conquista basada en la autoridad, la doctrina del honor, la honra, la discreción (especialmente la femenina), la lealtad, la asunción de la muerte de honor en la batalla, etc. En suma, Jorge Manrique, entre la Edad Media y el Renacimiento, aún vive y escribe como un guerrero. Eso da idea de que el discurso, aun nacido de y por razones extraliterarias, se estereotipa y crea unos clichés que valen para todos los poetas del momento.

Pero hay otro dato que me interesa aún más resaltar porque me parece más decisivo en la conformación final de los textos del amor cortés, especialmente de los siglos XIV y XV. Serrano de Haro lo analiza perfectamente en un capitulo de su estudio que titula «Salones de la época» (ibíd. 283 y ss.) que me parece fundamental para comprender la creación y recepción de este tipo de obras. En la alta sociedad del siglo XV la poesía no era más que un entretenimiento social. Los caballeros se reunían en tertulias literarias a competir en ingenio y audacia creando este tipo de poemas, lo que explica su recargada retórica. De modo que, además de la función lúdica, los poemas tenían una función social y se exhibían incluso delante de todos, en tiempo real, lo que explica también que las composiciones líricas estén viciadas de artificio. Estos juegos devenían en ocasiones en pequeñas competiciones entre los jugadores, muchas veces formulados en el género de preguntas y respuestas, las cuales intentaban ser progresivamente más ingeniosas. Nadie le daba demasiada importancia ni nadie se lo tomaba demasiado en serio. Serrano de Haro nos cuenta la anécdota de D. Álvaro Pérez de Guzmán, el cual diría que «tenía por necio al que no 
sabía hacer una copla, y por loco al que hacía dos» (ibíd. 283). En cualquier retrato de la época podemos encontrar a los señores en los salones de los palacios entregados a estos pasatiempos. Pero no debía pasar de pasatiempo. Dedicarse demasiado a ello estaba mal visto y quienes lo hacían tenían la necesidad de justificarse. El sentimiento de culpa partía de la convicción social de que era más valiosa la acción que la meditación y preferibles las armas a las letras.

La edición de las obras da fe de cuanto decimos, pues qué otra cosa son los cancioneros, las misceláneas, las florestas y los florilegios que colecciones de poemas de autores distintos. ¡Qué valioso es el estudio de la recepción en estos casos! Eso quiere decir que hay muchos aficionados a las letras pero muy pocos que se dediquen a ello de forma exclusiva, cuando muchos de ellos, siendo como eran de esa extracción social, podrían hacerlo. Y esto explica también la escasa producción de cancionero o, mejor dicho, lo poco que nos ha llegado, pues está claro que estas competiciones de ingenio no estaban destinadas a perdurar en el tiempo sino que, como todos los juegos, concluyen en la última partida, cuando se recogen las cartas, $\mathrm{y}$, por tanto, no tenían afán de posteridad. Por desgracia para los lectores de hoy aficionados a este tipo de poesía, la fama se buscaba por otros derroteros menos plácidos y más cruentos, tales como luchas fratricidas, «hacer guerra a los moros», y en este plan.

Concluyendo, toda la retórica del amor cortés, que en el siglo XV tiene su cristalización, es fruto de una poesía artificial, escrita por la antigua aristocracia feudal, ahora cultivada y refinada en sus costumbres, una aristocracia que utiliza la poesía como juego de salón que presenta gran complejidad formal debido a las competiciones de ingenio que se convocaban, las cuales consistían en expresarse dentro de un artificio métrico, de una variación temática estrecha y de una modulación formal y estilística encorsetadas. Serrano de Haro pone muchos ejemplos de ello, algunos verdaderamente dignos de mención ${ }^{7}$. Lo que ahora nos importa de ello es que la función de la poesía era más que nada lúdica, y eso contribuye sobremanera a explicar su diseño formal, las infinitas derivaciones y paronomasias, los juegos ingeniosos de palabras, los quiasmos, las fórmulas aforísticas, la búsqueda de la dificultad, el rizo del rizo. Esto explica el carácter intelectual de la poesía amorosa de este tiempo y su punto de vista, totalmente subjetivo: importa más la expresión de los sentimientos individuales que, por ejemplo, la descripción de la dama; interesa más el artificio retórico en la expresión del amor que la narración de acontecimientos, etc.

\footnotetext{
${ }^{7}$ Como aquel de un trovador que hace una colección de naipes poéticos a Isabel la Católica, o este otro que escribe seis poemas para sendas damas, las cuales debían cogerlo al azar dentro de una cesta (Serrano de Haro, 1975: 286).
} 
Sólo conociendo todos estos extremos podemos hacernos la idea de por qué este tipo de poesía amorosa, que tanto ha influido posteriormente, presenta este diseño. Si leemos el amor cortés sin conocer estos datos podemos incurrir en un error de exégesis de gran calibre, pues no ha de tomarse como real o sincero aquello que es sólo producto de un juego artificioso y una forma de entender la vida al servicio de la ideología de la clase poderosa. No se trata de que sea un tipo de poesía muy alejado de la realidad, tan sólo que el pacto de ficción que el lector hace con cualquier tipo de texto - incluido el lírico - se torna aquí doblemente especular. No es que sea falso, pues la literatura no es verdadera ni falsa, ya que es otro discurso paralelo a la realidad que juega a estar entre la verdad y la falsedad sin ser ninguna de ellas. No es falso; nos proporciona una imagen distorsionada de la realidad de su época, como todas las obras literarias, incluso de las realistas, como dijimos antes. Pero en este caso es doblemente especular porque en la génesis de su composición ya había público delante; se produjo en vivo y en directo, en tiempo real y, para más datos, en estrechos márgenes de tiempo, temática y forma; el pacto de lectura fue instantáneo en la mayoría de los casos. Esto debe conocerse para procurar atinar en la exégesis. La poesía del amor cortés en el siglo XV era llamada indistintamente poesía de cancionero, poesía de salón o poesía cortesana, lo que da idea de cuanto venimos diciendo. Los avatares de su producción, edición y recepción explican su viciada retórica y su pacto de lectura. Concluyamos este análisis con unas reveladoras palabras de Serrano de Haro sobre ese pacto de lectura:

«Los hombres de la segunda mitad del siglo XV vivían y se movían con comodidad en aquel clima de poética ficción. Conocían su falsedad, pero estaban familiarizados con él y lo aceptaban como una convención, con la misma naturalidad con que en los diversos tiempos y lugares han aceptado un código artístico, un diccionario de referencias. Se sabía perfectamente lo que aquella poesía quería decir, porque su ámbito de resonancia y su arquitectura crítica era la realidad social del estrado, del salón»

(Serrano de Haro, 1975: 287)

\section{EL CASO DE LOS TÓPICOS BARROCOS DEL HONOR Y LA HONRA}

Por último, vamos a intentar relacionar el concepto de modelos de mundo con los tópicos del amor y de la honra. Para ello voy a basarme en un excelente estudio de Cañas Murillo (1995), el cual analiza la importancia de este código literario en el teatro barroco ${ }^{8}$.

\footnotetext{
${ }^{8}$ El tema ha sido estudiado en profundidad por algunos de los mejores filólogos de nuestro país y por hispanistas de gran prestigio en el estudio de esta época (Rey Hazas, Díez Borque, Salomon, Maravall, Menéndez Pidal, Gustavo Correa, H. T. Ostendorp,
} 
En cuanto a la realidad extraliteraria del código del honor y de la honra, ha habido diversas teorías. Como el tema ha sido tan debatido, se ha llegado a algunas conclusiones. Quienes afirmaban que el código del honor literario tenía una correspondencia exacta en la sociedad del momento no es que estén equivocados, sino que han sido inexactos. La preocupación por la honra y el honor existen en la realidad de la España del Barroco. Pero el tema del honor tal como queda codificado en la comedia nueva es creación literaria, constituyente de un género que se va conformando con el paso de los años hasta llegar a la madurez del tópico $-\mathrm{y}$ cristalización - en el primer tercio del XVII. Antes, y sólo dentro del ámbito literario -demuestra Cañas Murillo (1995: 67-68) - existían vacilaciones y propuestas alternativas para los asuntos de honor. Prueba evidente de ello es la exclamación insertada en El leal criado (1594) de Lope de Vega, ejemplo que recoge Cañas Murillo (ibíd., 68): «Aunque has tu padre agraviado/ no está a matarte obligado,/ ni hay ley que lo mande ansí». No hallamos, pues, un código extraído de la realidad, sino que es convención literaria que viene a sumarse a otros tantos códigos cristalizados en la comedia nueva como la tipología de personajes (cuya estructura jerárquica está ideologizada por el poder, como ocurre en casi todas las obras literarias), el teocentrismo monárquico, etc. Como afirma Valbuena Prat a propósito de El alcalde de Zalamea de Calderón, el teatro barroco «buscó un acercamiento a la realidad a través de una convención literaria», no presenta un retrato de la vida sino un «vislumbre de la realidad dependiente de unas leyes literarias y un gusto poético, que se había impuesto previamente a la elaboración de la obra» (Valbuena, 1992: 29-31).

Ahora bien, cabe preguntarse en qué medida se alteraron los conceptos del honor y de la honra con respecto a los que estaban vigentes en la sociedad, quiénes lo hicieron y por qué. Tenemos respuestas contundentes para las tres preguntas. Los conceptos del honor y de la honra distorsionaron su referencia real en el sentido más tradicional, más conservador, más idílico y más de acuerdo con la mentalidad de la contrarreforma religiosa y social que se dio en el siglo XVII. Tras la sociedad renacentista - sin duda más abierta - del siglo XVI, se produjo en España una reacción señorial en el XVII, reflejo del absolutismo monárquico, de la restauración y del mantenimiento de un orden y de unos privilegios de clase. ¿Quiénes lo hicieron? No cabe duda que quien blandió la pluma fue el dramaturgo, pero

W. Fichter, Donald R. Larson) y creo que poco más se puede añadir. Una bibliografía muy ajustada sobre el tema aparece en Cañas Murillo, Jesús, Honor y honra en el primer Lope de Vega. Las comedias del destierro, Cáceres, Universidad de Extremadura, Servicio de Publicaciones, 1995 (Anejo del Anuario de Estudios Filológicos). Voy a limitarme a señalar los aspectos sociales e ideológicos que alberga el tema y sus relaciones con la sociedad de entonces para ver hasta qué punto el tema es reflejo de la sociedad del momento. 
al dictado de otros. Cañas Murillo (1995: 77-78) ha demostrado que en el tema del honor hubo en el origen diversas fluctuaciones, propuestas atrevidas, ausencias de castigos, en suma, dudas en la conformación del código. Por ejemplo, puede verse así en la exclamación insertada en El leal criado (1594) de Lope de Vega, donde leemos: «Aunque has tu padre agraviado/ no está a matarte obligado/ ni hay ley que lo mande así». No obstante, la intervención de la censura (protagonizada por moralistas y teólogos, garantes teóricos del orden establecido) condicionó decisivamente la configuración definitiva del tema del honor en el teatro. En el origen no tuvieron mucha intervención. Pero después, al convertirse el teatro en espectáculo de masas, empezaron a preocuparse por el contenido y a solicitar ciertos cuidados, a realizar algunas sugerencias, a enfocarlo de determinado modo, cuando no a boicotear una obra, suspender la función, cerrar el teatro o desterrar al dramaturgo. ¿Por qué se hizo? Ya hemos respondido a ello. La función es interesada. Casi siempre lo es. Salvo en los casos en que el modelo de mundo propuesto procede de algún sector de denuncia o de crisis de valores (me refiero, por ejemplo, a ciertos modelos de mundo creados por escritores como Valle-Inclán, Kafka, Beckett, Ionesco, Camus), los demás proceden del poder y de sus mecanismos de propaganda. Crear ese modelo de mundo ético en el XVII, aunque distorsionaba la realidad, era una forma de propaganda no ya sólo de una forma de actuar en caso de deshonra o pérdida del honor, sino una continua muestra de un tipo de sociedad, de un tipo de relaciones sociales, de un tipo determinado de jerarquía, de preocupaciones y hasta un modo concreto de evadirse de la realidad, pues hasta para evadirse de la realidad uno puede estar dirigido. Hasta nos han enseñado cómo ser libres.

\section{RECAPITULACIÓN}

Este artículo no pretende ser más que una ilustración. El concepto semiótico de «modelos de mundo», muy productivo en los últimos años, adquiere una interesante aplicación y proyección en el análisis e interpretación de textos literarios porque proporciona informaciones claves acerca del componente cultural, sociológico e ideológico de la literatura, tres ámbitos que redundan en la semántica y la exégesis textual. Me ha interesado, sobre todo, subrayar las relaciones que se establecen entre mundo real, modelo de mundo cultural y modelo de mundo literario/artístico. Tras realizar diversas calas teórico-prácticas en el Prerrenacimiento y el Barroco analizando los tópicos literarios del amor cortés y del honor y la honra, hemos llegado a la conclusión de que los modelos de mundo literarios se forjan a partir de la transformación interesada de los modelos de mundo culturales, los cuales, a su vez, son también tendenciosos con respecto a 
la realidad; lo interesante es analizar el desvío que muestra el modelo de mundo literario con respecto al real, en qué consiste ese desvío y por qué se ha producido. Los modelos de mundo literarios siempre ofrecen una imagen distorsionada del mundo real, incluso en el Realismo, quizá el modelo literario menos distorsionado en relación al real pero, por eso mismo, probablemente el más engañoso. La distorsión puede ser mínima o puede llegar a alcanzar cotas de idealismo, caricatura o absoluta desfiguración. Las causas de la transformación obedecen a dos factores: culturales e ideológicos, los cuales suelen aparecer unidos y, por tanto, son difícilmente discernibles. Los factores ideológicos, mucho más importantes, tienen casi siempre su origen en el poder, en las clases poderosas o en los escritores complacientes con el poder, lo que viene a ser lo mismo. La intención final del poder es conservar su mundo, sus privilegios y su patrimonio y, curiosamente, para conseguirlo o salvaguardarlo, no crea un modelo de mundo literario idéntico al suyo sino sutilmente distorsionado, de manera que la ficción oculte la ideología pero ésta habite subyacente entre líneas mostrando y ocultando los hábitos sociales que le son gratos, la estructura social que le beneficia y los valores que son los valores de su clase.

\section{BIBLIOGRAFÍA}

AlbadAlejo MAYORDOMO, Tomás, Teoría de los mundos posibles y macroestructura narrativa, Universidad de Alicante, Secretariado de Publicaciones, 1986.

AMORós, Amparo, La palabra del silencio (La función del silencio en la poesía a partir de 1969), tesis doctoral, Madrid, Universidad Complutense, 1991.

BARTHES, Roland (1970), El imperio de los signos (trad. de Adolfo García Ortega), Ginebra, Mondadori, 1990.

Blanchot, Maurice (1955), El espacio literario (trad. de Jorge Jinkis), Buenos Aires, Paidós, 1969.

BOURDIEU, Pierre (1992), Las reglas del arte. Génesis y estructura del campo literario (trad. de Thomas Kauf), Barcelona, Anagrama, 1995.

CAÑAS MURILlo, Jesús, Honor y honra en el primer Lope de Vega. Las comedias del destierro, Cáceres, Universidad de Extremadura, Servicio de Publicaciones (Anejo del Anuario de Estudios Filológicos), 1995.

CARNERo, Guillermo, «Reflexiones egocéntricas III: Naturaleza y paisaje en Dibujo de la muerte (1967-1990)», Letra Internacional, 69, invierno, 2000, 20-25.

CAstiglione, Baltasar de, El Cortesano (trad. de Juan Boscán), Barcelona, Bruguera, 1972.

CHARTIER, Roger, El juego de las reglas: lecturas, Buenos Aires, F. C. E., 2000.

CURTIUS, Ernst Robert (1948), Literatura Europea y Edad Media Latina, (trad. de Margit F. Alatorre), México, F. C. E., 1977.

DÄLlENBACH, Lucien (1977), El relato especular, (trad. de Ramón Buenaventura), Madrid, Visor, 1991.

DAVIS, Lennard (1997), Resistirse a la novela. Novelas para resistir. Ideología y ficción (trad. de Ricardo García Pérez), Barcelona, Debate, 2002.

DERRIDA, Jacques, De la gramatología (trad. de Óscar del Barco), Argentina, Siglo XXI, 1967. 
DOLEŽEL, Lubomir (1979), «Extensional and Intensional narrative worlds», en Poetics, 8, pp. 521-530.

- (1980), «Truth and Authenticity in Narrative», Poetics Today, I, 3, 1980, pp. 7-25. Cito por la versión castellana, "Verdad y autenticidad narrativa», en Garrido Domínguez, Antonio (ed.), Teorías de la ficción literaria, Madrid, Arco/Libros, 1997, pp. 95-122.

- (1988), «Mimesis and Possible Worlds», en Poetics Today, 9, 3, pp. 475-496. Cito por la versión castellana, «Mímesis y mundos posibles», en Garrido Domínguez, Antonio (ed.), Teorías de la ficción literaria, Arco/Libros, 1997, pp. 69-94.

GALÁN RODRÍGUEZ, Carmen, "La teoría lingüística de Wilhelm Von Humboldt», Anuario de Estudios filológicos, Universidad de Extremadura, XVII, 1994, pp. 165-185.

GARRIDO GALlARDO, Miguel Ángel, «Una clave interpretativa para tres recursos literarios fundamentales en Los Milagros de Nuestra Señora: la alegoría, el protagonismo absoluto y el final feliz», Revista de Filología Española, LIX, 1979, pp. 279-284. También en Garrido Gallardo (1996), pp. 213-223.

- La crítica literaria. La doctrina de Lucien Goldmann, Madrid, Rialp, 1996.

Goodman, Nelson, Maneras de hacer mundos (trad. de Carlos Thiebaut), Madrid, La Balsa de la Medusa (Visor),' 1978.

HARSHAW, Benjamin (1984), «Fictionality and Fields of Reference. Remarks on a Theoretical Framework», Poetics Today, 5, 2, pp. 227-251. Cito por la versión castellana, «Ficcionalidad y campos de referencia», en Farrido Domínguez, Antonio (ed.), Teorías de la ficción literaria, Madrid, Arco/Libros, 1997, pp. 123-158.

Humboldt, Wilhelm Von, Escritos sobre el lenguaje (trad. de Andrés Sánchez Pascual) (prólogo de José María Valverde), Barcelona, Península, 1991. Contiene cinco artículos publicados originalmente entre 1820 y 1835.

HutCheON, Linda (1980), Narcissistic narrative. The Metafictional Paradox, London \& New York, Methuen, 1984.

JASPERS, Karl, (1948-1952), Lo trágico. El lenguaje (ed. de José Luis del Barco), Granada, ed. Agora, 1995.

LÉVY-STRAuSS, Claude (1987), Mito y significado (trad. de Héctor Arruabarrena), Madrid, Alianza, 1999.

LIDA DE MALKIEL, Rosa, «Transmisión y recreación de temas grecolatinos en la poesía lírica española», en Revista de Filología Hispánica, I, 1959, 20-63.

Lotman, Y. M. y Escuela DE TARTU (1970), Semiótica de la cultura, (trad. de Nieves Méndez), Madrid, Cátedra, 1979.

MARINA, J. Antonio, El rompecabezas de la sexualidad, Barcelona, Anagrama, 2002.

MCLuhan, M. (1962), La galaxia Gutemberg. Génesis del homo tipographicus (trad. de Juan Novella), Madrid, Aguilar, 1972.

Pavel, T. (1983), «Las fronteras de la ficción» (trad. de Mariano Baselga), en Teorías de la ficción literaria, Garrido Domínguez, A. (ed.), Madrid, Arco/Libros, 1997, 171179.

PÉRez PARejo, Ramón, Metapoesía y crítica del lenguaje (De la generación de los 50 a los novísimos), Cáceres, Servicio de Publicaciones de la Universidad de Extremadura, 2002.

Pozuelo Yvancos, José María, Teoría del lenguaje literario, Madrid, Cátedra, 1988.

RobBe-Grillet, Alain (1963), Por una nueva novela (trad. de Caridad Martínez), Barcelona, Seix Barral, 1973.

RYAN, Marie-Laure (1991), «Possible Worlds and accesibility Relations. A Semantic Typology of Fiction», en Possible Worlds, Artificial Inteligence and Narrative Theory, Bloomington, IN, Indianapolis University Press, pp. 31-47. Cito por la versión castellana en Garrido Domínguez, Antonio (ed.), Teoría de la ficción literarias, Madrid, Arco/Libros, 1997, pp. 181-206. 
SÁNCHEZ-PARdo GonZÁleZ, Esther, Postmodernismo y metaficción, Madrid, Universidad Complutense (tesis doctoral), 1991.

SANZ CABRERIzo, Amelia, «La noción de intertextualidad hoy», en Revista de Literatura, tomo LVII, n. ${ }^{\circ} 114,1995,341-362$.

SCHMIDT, Siegfried J. (1984), «La auténtica ficción es que la realidad existe. Modelo constructivista de la realidad, la ficción y la literatura» (trad. de Paloma Tejada Caller), en Teorías de la ficción literaria, GARRIDo DOMíngUEZ, Antonio (ed.), Madrid, Arco/Libros, 1997, 207-238.

SEGRE, Cesare (1974), Las estructuras y el tiempo. Narración, poesía, modelos (trad. de Milagros Arizmendi), Barcelona, Planeta, 1976.

- Principios de análisis del texto literario (trad. de Mariola Pardo de Santayana), Barcelona, Crítica, 1985.

- Semiótica filológica. Texto y modelos culturales, Murcia, Universidad de Murcia, 1990.

SERRANO DE HARO, Antonio, Personalidad y destino de Jorge Manrique, Madrid, Gredos, 1985.

STEINER, George (1967), Lenguaje y silencio. Ensayos sobre la literatura, el lenguaje y lo inhumano (trad. de Miguel Ultorio), México, Gedisa, 1982. Recoge artículos originales del autor entre 1956 y 1966.

VAlbuena BrIONES, Ángel, «Prólogo» a Pedro Calderón de la Barca, El alcalde de Zalamea, Madrid, Cátedra, 1992, 11-5.

VICTORIO, Juan, El amor y el erotismo en la literatura medieval, Madrid, ed. de J. García Verdugo, 1995. 


\title{
RESUMEN
}

Modelos de mundo y tópicos literarios: la construcción ficcional al servicio de la ideología del poder, por Ramón Pérez Parejo.

En síntesis, por modelos de mundo se entiende la percepción cultural que el sujeto tiene del mundo al que pertenece. El concepto, que procede de la Semiótica de la Cultura desarrollada por la Escuela de Tartu-Moscú en los años setenta, adquiere una interesante proyección en Literatura porque informa sobre el componente cultural e ideológico que comporta todo desvío ficcional. Hemos señalado las relaciones y desajustes que se establecen entre mundo real, modelo de mundo cultural y modelo de mundo literario/artístico. Estos últimos se forjan a partir de la transformación interesada de la realidad. Esa distorsión ficcional puede resultar mínima o llegar a alcanzar cotas de idealismo, caricatura o absoluta desfiguración. Se debe analizar ese desvío ficcional, cuál es su medida, en qué consiste, quién lo ha realizado y por qué. Las razones son culturales e ideológicas, y sus agentes están vinculados casi siempre con las clases poderosas. Construyendo estos mundos virtuales, la intención final del poder es conservar su propio mundo, sus privilegios y su patrimonio.

Palabras clave: modelos de mundo, ficción, ideología, cultura, desvío ficcional.

\begin{abstract}
To sum up, by world views we understand the cultural perception of the world we belong to. This concept of world views, that comes from the Semiotic of Culture developed by the School of Tartu-Moscow in the seventies, reaches an interesting scope in Literature as it offers information about cultural and ideological components that are part of any fictional trasformation. In this article we have shown the relationships and disagreements established between real world and the cultural and literary /artistic view of the world. This cultural / literary / artistic views are shaped from a recreation of reality based on different interests. Fictional transformation can be a small one or can reach a high level of idealization, caricature or complete alteration. This fictional distortion must be analysed together with its scope, how it is produced, who has decided to produce it and why. We will find out that there are both cultural and ideological reasons and those who produce these transformations have often something to do with the ruling classes. By building these virtual worlds they are just trying to preserve their power, their privileges and their possessions.
\end{abstract}

Key words: world views, fiction, ideology, culture, fictional distortion. 